\title{
PARTISIPASI MASYARAKAT DALAM PROGRAM PENINGKATAN KUALITAS RUMAH TIDAK LAYAK HUNI DI KOTA PAYAKUMBUH
}

\author{
Defi Fradila Sari \\ Email: defifradilasari@gmail.com \\ Jurusan Pembangunan Wilayah Pedesaan Pascasarjana Universitas Andalas Padang \\ Jl. Limau Manis Kec. Pauh, Kota Padang \\ Erwin \\ Email: Erwin@gmail.com \\ Jurusan Pembangunan Wilayah Pedesaan Pascasarjana Universitas Andalas Padang \\ Jl. Limau Manis Kec. Pauh, Kota Padang \\ Afrizal M \\ Email: Afrizal@gmail.com \\ Jurusan Pembangunan Wilayah Pedesaan Pascasarjana Universitas Andalas Padang \\ Jl. Limau Manis Kec. Pauh, Kota Padang
}

\begin{abstract}
ABSTRAK
Tujuan penelitian ini adalah: 1) Menjelaskan ruang lingkup partisipasi masyarakat dalam perencanaan dan pelaksanaan Peningkatan Kualitas Rumah Tidak Layak Huni (PK-RTLH) di Payakumbuh. 2) Menganalisis faktor pendukung dan penghambat partisipasi dalam pelaksanaan program Peningkatan Kualitas Rumah Tidak Layak Huni (PK-RTLH) di Payakumbuh. Penelitian ini dilakukan di Kota Payakumbuh. Waktu penelitian dilakukan pada bulan Januari sampai Februari 2020. Penelitian ini menggunakan metode kualitatif. Informan penelitian berjumlah 22 orang yang terdiri dari 17 informan kunci dan 5 informan biasa. Berdasarkan hasil penelitian bentuk partisipasi masyarakat dalam perencanaan Peningkatan Mutu Rumah Rehabilitasi Rumah Tidak Layak Huni adalah; a) Pembentukan kelompok penerima bantuan; b) Buka nomor rekening untuk penerima manfaat; c) Memanfaatkan sumber daya lokal. Bentuk partisipasi masyarakat dalam pelaksanaan Program Peningkatan Kualitas Rehabilitasi Rumah Tidak Layak Huni: a) Partisipasi berupa pendampingan dari pekerja; b) Partisipasi dalam bentuk bantuan material; c) Partisipasi dalam bentuk keterampilan atau keahlian. Faktor yang memungkinkan masyarakat untuk berpartisipasi adalah internal (intrinsik) dan eksternal (ekstrinsik). Dalam partisipasi juga terdapat faktor-faktor yang menghambat masyarakat untuk berpartisipasi, yaitu: a) Faktor ekonomi; b) Pengaruh modernisasi sehingga muncul individualisme; c) Informasi program tidak menjangkau seluruh elemen masyarakat.
\end{abstract}

Kata kunci: Pembangunan, Partisipasi, Rumah, Miskin

\section{ABSTRACT}

The objectives of this study are: 1) To explain the scope of community participation in planning and implementing Improvement of Quality of Non-Habitable Homes (PK-RTLH) in Payakumbuh. 2) To analyze the enabling and inhibiting factors of participation in the implementation of the Improvement of the Quality of Uninhabitable Homes (PK-RTLH) program in Payakumbuh. This research was conducted in the City of Payakumbuh. The time of the study was conducted in January to February 2020. This study used a qualitative method. There were 22 research informants consisting of 17 key informants and 5 ordinary informants. Based on the results of research the form of community participation in the planning of Improvement of the Quality of Rehab Homes for Non-Habitable Homes are; a) Formation of groups of aid recipients; b) Open account numbers for beneficiaries; c) Utilizing local resources. Forms of community participation in the implementation of the Improvement Program for the Quality of Rehabilitation of Non-Habitable Homes: a) Participation in the form of assistance from workers; b) Participation in the form of material assistance; c) Participation in the form of skills or expertise. Enabling factors for the community to participate are internal (intrinsic) and external (extrinsic). In participation there are also factors that inhibit people from participating, namely: a) Economic factors; b) The effect of modernization so that individualism emerges; c) Program information does not reach all elements of the community.

Keywords: Development, Participation, House, Poor 


\section{PENDAHULUAN}

Kemiskinan merupakan permasalahan yang dihadapi baik oleh negara miskin maupun negara maju. Berbagai upaya telah dilakukan oleh pemerintah dalam mengentaskan kemiskinan melalui banyak program. Salah satunya adalah melalui program Peningkatan Kualitas Rumah Tidak Layak Huni yang dianggarkan oleh pemerintah pusat dan pemerintah daerah. Kemiskinan tidak hanya terjadi di desa tetapi juga di kota. Melalui pemberian bantuan rumah tidak layak huni ini diharapkan terpenuhinya kebutuhan dasar masyarakat miskin terhadap kebutuhan perumahan. Oleh karena itu kebutuhan akan perumahan adalah kebutuhan yang mendasar untuk masyarakat miskin atau masyarakat rentan ekonomi.

Untuk mengatasi kemiskinan di Kota Payakumbuh dilakukan berbagai program pengentasan kemiskinan diantaranya Program peningkatan Kualitas Rumah Tidak Layak Huni untuk keluarga berpenghasilan rendah yang direkomendasikan oleh kelurahan masing-masing. Berikut data pelaksanaan Peningkatan Kualitas Rumah Tidak Layak Huni di Kota Payakumbuh. Kota Payakumbuh terdiri dari 47 kelurahan dengan jumlah Rumah Tidak Layak Huni sejumlah 2.660 unit, sedangkan yang terealisasi tahun 2017 sebanyak 356 unit dan tahun 2018 sebanyak 309 unit. Dengan kata lain yang baru terealisasi selama 2 tahun yaitu 665 unit dan masih terdapat 1.995 unit rumah lagi yang harus direhab (BPS, 2018).

Terdapat potensi yang besar dalam program Bantuan Rumah Swadaya ini diantaranya menggunakan sistem pembangunan partisipatif. Penerima bantuan serta masyarakat turut aktif merencanakan dan melaksanakan kegiatan dengan membentuk kelompok penerima bantuan yang bertanggungjawab dalam proses pengambilan keputusan, bergotong royong dalam proses pelaksanaan Peningkatan Kualitas Rumah Tidak Layak Huni, melakukan penarikan kembali bantuan apabila terdapat anggota yang tidak menyelesaikan pekerjaan dan bertanggungjawab terhadap pemanfaatan bantuan secara tanggung renteng.

Pentingnya partisipasi dalam program pembangunan Rumah Tidak Layak Huni ini karena selain salah satu program pengentasan kemiskinan juga untuk memaksimalkan hasil dari pembangunan. Tinggi rendahnya partisipasi berhubungan langsung dengan sukses atau tidaknya hasil akhir pembangunan. Dengan adanya partisipasi pekerjaan lebih mudah dan lebih banyak yang dicapai dan dapat dijadikan katalisator untuk pembangunan berikutnya.

Pada dua tahun terakhir (2017-2018) kecamatan yang berhasil melaksanakan program ini adalah Kecamatan Payakumbuh Utara, Kecamatan Lampasi Tigo Nagari. Tingkat partisipasi masyarakat cukup tinggi di kecamatan tersebut dibuktikan dengan cukup bagusnya hasil 
pembangunan rumah serta tingginya kerjasama masyarakat yang berkontribusi dalam program tersebut.

Program Peningkatan Kualitas Rumah Tidak Layak Huni seharusnya menjadi stimulus bagi masyarakat untuk ikut serta berpartisipasi mendukung program tersebut, karena Pemerintah seharusnya hanya sebagai katalisator dan fasilitator untuk membangkitkan keinginan masyarakat sekitar untuk ikut turut serta dalam mendukung program pembangunan tersebut. Namun tidak demikian yang terjadi di lapangan, karena terjadi keterlambatan proses rehab rumah. Hal ini disebabkan kurangnya kesadaran masyarakat sekitar untuk ikut serta membantu pembangunan tersebut karena tidak disemua tempat program ini berjalan sesuai dengan yang diharapkan.

Tujuan penelitian ini adalah: 1) Untuk menjelaskan ruang lingkup partisipasi masyarakat dalam perencanaan dan pelaksanaan Peningkatan Kualitas Rumah Tidak Layak Huni (PK-RTLH) di kota Payakumbuh. 2) Untuk menganalisis faktor pemungkin dan penghambat partisipasi dalam pelaksanaan program Peningkatan Kualitas Rumah Tidak Layak Huni (PK-RTLH) di kota Payakumbuh

\section{METODE PENELITIAN}

Penelitian ini dilakukan di Kota Payakumbuh dengan mengambil lokasi di Kecamatan Payakumbuh Barat (Kelurahan Payolansek, Kelurahan Padangtangah Balainanduo), Kecamatan Lampasi Tigo Nagari (Kelurahan Koto Panjang Dalam), Kecamatan Payakumbuh Utara (Kelurahan Tigo Koto Diateh). Penelitian ini menggunakan metode kualitatif. Informan penelitian berjumlah 22 orang terdiri dari 17 orang informan kunci dan 5 orang informan biasa. Informan kunci adalah penerima bantuan program PK-RTLH sedangkan untuk informan biasa terdiri dari 2 orang fasilitator dan 1 orang Kabid Perumahan Rakyat dan Kawasan Pemukiman dan 1 orang Lurah serta 1 orang Niniak Mamak.

\section{HASIL DAN PEMBAHASAN}

Masyarakat kota Payakumbuh yang tinggal didaerah dengan mayoritas pribumi dan saling mengenal memiliki ikatan kekerabatan yang tinggi dibandingkan dengan yang sudah bercampur dengan pendatang. Masih ada ikatan kesukuan dan menghargai ninik mamak, cadiak pandai dan alim ulama ditempat tersebut. Hal ini dibuktikan dengan masih dilibatkan dalam setiap pengambilan keputusan apapun dalam kelurahan. 
Adanya peran Lurah sebagai perpanjangan tangan pemerintah, LPM, RT/RW, Niniak Mamak, tokoh masyarakat dalam setiap forum rapat ataupun dalam setiap adanya program baru dari Pemerintah Daerah maupun Pusat. Adanya kearifan lokal yang juga harus dipertimbangkan oleh setiap adanya program yang masuk ke daerah tersebut.

Rehab rumah tidak layak huni merupakan bantuan rumah dengan memberikan stimulan kepada masyarakat rentan ekonomi atau masyarakat miskin berupa bahan bangunan untuk tujuan memancing masyarakat membantu secara bersama atau gotong royong membangun rumah tersebut agar layak untuk dihuni.

Masyarakat yang dimaksud dalam penelitian terdiri dari anggota kekerabatan, ketetanggaan maupun dari RT/RW, LPM, pimpinan kaum dan tokoh masyarakat setempat. Diharapkan adanya partisipasi yang bisa berupa partisipasi ide, pikiran atau gagasan kemudian partisipasi berupa tenaga, harta benda dan kemahiran.

Penelitian ini khusus mengkaji implementasi Program Rehab Rumah Tidak Layak Huni tahun 2017-2018. Dimana jumlah bantuan pada tahun 2017 sejumlah Rp. 10 juta dan tahun 2018 sejumlah Rp. 15 juta. Dinas Perumahan Rakyat dan Kawasan Pemukiman merupakan pelaksana program tersebut semenjak Desember 2016. Maka pada tahun 2017 khusus untuk program rehab rumah swadaya ini berada di Dinas Perumahan Rakyat dan Kawasan Pemukiman yang sebelumnya bantuan rumah ini dilaksanakan oleh Dinas Sosial dan Tenaga Kerja.

Tahun 2017 awal dari pelaksanaan program ini sejak dipindahkan ke Dinas Perumahan Rakyat dan Kawasan Pemukiman maka mulailah dilaksanakan pada triwulan ke 2 dengan didasarkan pada Undang-Undang Nomor 11 Tahun 2011 tentang Perumahan dan Kawasan Pemukiman. Adapun persyaratan untuk memperoleh bantuan adalah sebagai berikut:

1. Warga negara Indonesia yang sudah berkeluarga. Penerima bantuan diharuskan yang sudah berkeluarga punya tanggung jawab menafkahi keluarga.

2. Memiliki satu-satunya rumah dalam kondisi tidak layak huni. Rumah yang dimiliki calon penerima bantuan merupakan rumah satu-satunya dan memenuhi kritteria rumah tidak layak huni.

3. Memiliki atau dapat menguasai tanah. Tanah yang diatasnya berada rumah tidak layak huni tersebut dikuasai oleh calon penerima bantuan dibuktikan dengan Sertifikat Hak Milik atas nama Kepala Keluarga calon penerima bantuan.

4. Lokasi Bantuan Rumah Swadaya sesuai RTRW (Rencana Tata Ruang Wilayah). Rumah yang akan direhab tentunya harus sesuai dengan RTRW yang dikeluarkan oleh Dinas PU dan Tata 
Ruang Kota Payakumbuh. Jika berada di rencana perluasan jalan maka otomatis rumah tersebut tidak bisa direhab.

5. Belum pernah memperoleh Bantuan Rumah Swadaya atau program sejenis. Pemerintah harus memastikan terlebih dahulu bahwa calon penerima bantuan tersebut belum pernah menerima bantuan rehab rumah sebelumnya.

6. Berpenghasilan paling banyak sebesar upah minimum provinsi yaitu Rp. 2.289.228,-. Penerima bantuan rumah swadaya ini merupakan keluarga miskin yang penghasilan mereka dibawah upah minimun propinsi.

7. Bersedia berswadaya dan membentuk kelompok. Persyaratan yang harus dipenuhi terakhir yaitu komitmen untuk berswadaya dan membentuk kelompok penerima bantuan yang terdiri dari ketua, sekretaris dan anggota.

\section{Mekanisme pelaksanaan Program}

Adapun mekanisme pelaksanaan kegiatan Peningkatan Kualitas Rumah Tidak Layak Huni di Kota Payakumbuh adalah sebagai berikut:

1. Persiapan

a. Sosialisasi dan penyuluhan

- Kegiatan sosialisasi dilakukan oleh dinas Perumahan dan Kawasan Pemukiman Kota Payakumbuh yang difasilitasi oleh perangkat kelurahan dan Tenaga Fasilitator Lapangan (TFL) dengan mengundang RT/RW, LPM, Niniak Mamak, Tokoh Masyarakat dan calon penerima bantuan. Kegiatan ini dilakukan untuk memberikan petunjuk dan bimbingan kepada masyarakat khususnya yang akan terlibat langsung dalam program yaitu calon penerima bantuan. hal yang disampaikan adalah prosedur kegiatan, tata cara mengikuti program, tanggung jawab penerima bantuan, sanksi dan ketentuan rumah layak huni, penyusunan rencana anggaran biaya, pelaporan dan usaha stakeholder kelurahan untuk menggerakkan swadaya masyarakat untuk membantu penerima bantuan nantinya.

b. Verifikasi calon penerima bantuan

- Kegiatan selanjutnya yang dilakukan adalah pemeriksaan data masyarakat yang dilakukan secara administrasi dan faktual agar calon penerima bantuan sesuai kriteria yang telah ditentukan.

- Tenaga Fasilitator Lapangan melakukan verifikasi yang didampingi Lurah/RT/RW dengan mendatangi rumah atau berdasarkan data yang sudah didapat sebelumnya. 
c. Identifikasi calon penerima bantuan

- Kegiatan ini bertujuan untuk mengetahui kemampuan masyarakat berswadaya dan kemampuan sipenerima bantuan untuk berswadaya.

Pengidentifikasian rencana penanganan rumah untuk kebutuhan peningkatan kualitas rumah.

- Identifikasi calon penerima bantuan untuk bertukang, karena dana untuk upah tukang tidak ada maka hal ini perlu disepakati bagaimana komitmen calon penerima bantuan mengatasinya hal ini juga harus diketahui RT/RW dan Niniak Mamak.

d. Kesepakatan calon penerima bantuan (Rembuk Warga)

Program ini dilakukan tentunya memenuhi syarat akuntabilitas dan berlandaskan prinsip tepat sasaran dan gotong royong. Kesepakatan diprakarsai oleh masyarakat calon penerima bantuan dan difasilitsi oleh TFL, Lurah dan perangkatnya, RT/RW, Niniak Mamak, tokoh masyarakat serta masyarakat lain yang dirasa mampu berkontribusi (donatur).

2. Penetapan penerima bantuan, untuk membuka rekening atas nama penerima bantuan ditetapkanlah dengan Surat Keputusan Walikota yang menjadi dasar pembayaran.

\section{Pencairan Bantuan}

Pencairan bantuan dana setelah ditandatangani langsung ditransfer pihak bank ke rekening penerima bantuan namun tidak dapat mereka cairkan karena bank kemudian memindahkan ke toko bangunan. Pencairan tersebut dibagi kedalam 2 (dua) tahap pada bulan Agustus dan bulan Oktober. Jadi selama itu proses pembangunan akan berlangsung yang dibagi kedalam 2 tahap yaitu $30 \%$ dan $70 \%$.

4. Penyaluran Bantuan

Penyaluran bantuan berupa bahan bangunan yang telah disesuaikan dengan Rencana Anggaran Biaya (RAB) dalam proposal yang telah diajukan oleh penerima bantuan sebelumnya.

5. Pemanfaatan bantuan

Bahan bangunan yang telah diberikan tersebut dimanfaatkan sesuai kebutuhan rumah masing-masing penerima bantuan. Bahan bangunan berupa kayu, pasir, bata, besi dan papan untuk merehab rumah.

6. Dokumentasi

Semua tahapan didokumentasikan mulai dari rembuk warga, rumah yang direhab $30 \%$ dan rumah sudah jadi 100\% didokumentasikan oleh Fasilitator. 


\section{Ruang Lingkup Partisipasi}

\section{Bentuk Partisipasi Masyarakat Dalam Perencanaan Program Rumah Tidak Layak Huni (PK-RTLH)}

Partisipasi masyarakat dalam perencanaan program ini merupakan langkah awal dalam perumusan secara teknis dan prosedur untuk keberlangsungan kesuksesan program kedepannya. Keterlibatan masyarakat semenjak proses perencanaan, menjadi langkah yang tepat demi keefisienan berjalannya program. Di sisi lain, partisipasi yang timbul semenjak proses perencanaan juga sesuai dengan harapan yang terkandung pada program itu sendiri. Hal ini dimana bantuan yang diberikan oleh pemerintah dalam program Peningkatan Kualitas Rumah Tidak Layak Huni (PK-RTLH) tersebut dapat dipandang sebagai stimulan agar tercipta wacana peningkatan kualitas hidup sesama warga di daerah lingkungan sosial disekitar mereka.

Proses perencanaan bermula dengan adanya rapat dan forum sebelum pembangunan dimulai. Pihak-pihak terkait seperti LPM, Ketua RT/RW, Niniak Mamak dan tokoh masyarakat dilibatkan dalam mensosialisasikan program, sehingga program tersebut dapat diterima dan didukung oleh masyarakat. Dilibatkannya tokoh setempat juga diharapkan dapat membantu dan menggerakkan partisipasi masyarakat karena bantuan yang diberikan hanya sebagai stimulan, dan kemudian lebih mengandalkan swadaya bersama kalangan masyarakat setempat.

a. Pembentukan Kelompok Penerima Bantuan

Sebagai inisiator program Peningkatan Kualitas Rumah Tidak Layak Huni, maka Dinas Perumahan Rakyat dan Kawasan Pemukiman Pemerintah Kota Payakumbuh terlebih dahulu telah turun ke lapangan untuk mensosialisasikan program tersebut. Demi kesuksesan program, segala informasi yang terkait harus dapat disampaikan kepada masyarakat luas.

Proses perencanaan dalam program PK-RTLH ini dapat dilihat saat musyawarah atau mufakat pada tahap sosialisasi serta perencanaan program. Pihak Dinas Perumahan Rakyat dan Kawasan Pemukiman melakukan beberapa kali sosialisasi yang difasilitasi oleh Lurah dengan mengundang RT/RW, LPM, Niniak Mamak dan tokoh masyarakat serta calon penerima bantuan. Tinggi atau rendahnya partisipasi pada tingkat perencanaan dapat dilihat pada tingkat kehadiran pada saat rembuk warga.

Kegiatan ini dilakukan untuk memberikan petunjuk dan bimbingan kepada masyarakat khususnya yang akan terlibat langsung dalam program yaitu calon penerima bantuan. Hal yang disampaikan adalah prosedur kegiatan, tata cara mengikuti program, tanggung jawab penerima 
bantuan, sanksi dan ketentuan rumah layak huni, penyusunan rencana anggaran biaya, pelaporan dan usaha menggerakkan swadaya masyarakat untuk membantu penerima bantuan nantinya.

a. Membuka nomor rekening untuk penerima bantuan

Setelah kelompok-kelompok penerima bantuan terbentuk, maka tahap perencanaan selanjutnya ialah pembukaan nomor rekening bank atas nama penerima bantuan. Proses pembuatan rekening bantuan dilaksanakan di kelurahan yang bekerjasama dengan pihak Bank. Petugas Bank langsung datang ke kantor Lurah dan melakukan proses pembuatan rekening penerima bantuan. Nomor rekening ini selanjutnya akan menjadi kanal penyaluran uang bantuan bagi para penerima bantuan yang tergabung dalam kelompok-kelompok yang sudah dibentuk sebelumnya, dalam program tersebut.

b. Mendayagunakan Sumber Daya Lokal

Setelah sosialisasi program dilakukan oleh pihak dinas terkait langsung kepada masyarakat, maka langkah-langkah untuk implementasi program mulai disusun satu-persatu. Sesudah mengidentifikasi anggota masyarakat yang berhak untuk penerima bantuan dan kemudian mengelompokkan mereka, maka ada satu langkah lagi yang harus dilakukan sebelum pelaksanaan program dilakukan. Hal itu ialah menunjuk potensi dan sumber daya di lingkungan sekitar, yang bisa diberdayagunakan demi kesuksesan program. Sebagai program yang membutuhkan partisipasi yang luas dari masyarakat di sekitarnya, maka segala potensi dan sumber daya yang ada harus mampu dimaksimalkan demi kelancaran implementasi dan pelaksanaannya.

Salah satu bentuk kebutuhan sumber daya lokal yang paling vital adalah kesediaan toko-toko bangunan di sekitar lokasi sebagai penyuplai bahan-bahan bangunan. Toko bangunan yang ditunjuk memang diprioritaskan yang berada pada satu kawasan dengan kelurahan pelaksana program. Selain atas pertimbangan mempermudah proses pengantaran barang, penunjukkan toko yang berada di kawasan yang sama juga bermaksud agar semakin banyak warga di sekitar merasakan keterlibatan dengan adanya program PK-RTLH ini. Di sisi lain, juga ada faktor kedekatan dan keakraban dengan masyarakat sekitar, karena sebagian besar pemilik toko bangunan tersebut juga merupakan penduduk pribumi setempat.

\section{Bentuk Partisipasi Masyarakat Dalam Pelaksanaan Program Rumah Tidak Layak Huni (PK-RTLH)}

Partisipasi masyarakat membutuhkan keikutsertaan masyarakat di dalam pembangunan mulai dari perencanaan maupun dalam pelaksanaan suatu program. Dengan adanya partisipasi maka 
masyarakat ikut terlibat di dalam kegiatan pemerintah, karena tanpa keterlibatan masyarakat proses kegiatan tentunya kurang maksimal.

a. Partisipasi Berupa Bantuan Tenaga

Masyarakat yang ikut serta dalam membantu proses pembangunan rehab Rumah Tidak Layak Huni tentunya tidak hanya dalam bentuk memberikan ide atau gagasan, melainkan juga dapat berupa tenaga. Meskipun berada secara geografis di daerah perkotaan, akan tetapi masyarakat kota Payakumbuh secara holistik masih terbilang masyarakat yang sarat dengan nilai-nilai komunalisme. Setidaknya hal tersebut terlihat dari cara para warga berpartisipasi dalam program PK-RTLH tersebut.

\section{b. Partisipasi Berupa Bantuan Materi}

Partisipasi materi adalah keterlibatan masyarakat dalam membantu implementasi dan pelaksanaan program, dengan bantuan yang berupa uang, makanan, bahan bangunan dan sebagainya. Beragamnya bentuk bantuan materi yang digalang oleh masyarakat, secara nilai memang cukup bervariasi. Namun demikian, tetap saja menunjukkan dengan jelas tingginya tingkat partisipasi masyareakat sekitar terhadap program PK-RTLH di Kota Payakumbuh.

c. Partisipasi Berupa Keterampilan/ Keahlian

Dalam tahap pelaksanaan program, selain memberikan bantuan materi dan tenaga, satu lagi jenis partisipasi yang ada ialah dengan memberikan kontribusi berupa keterampilan ataupun keahlian khusus. Keahlian khusus ini berupa kemampuan yang berguna dalam proses pengerjaan renovasi rumah, seperti keahlian bertukang bangunan ataupun kayu. Partisipasi yang diberikan ialah dalam bentuk keahlian dalam merancang rumah, keahlian dalam merencanakan anggaran biaya pembangunan rumah dan lain sebagainya.

\section{Tingkatan Partisipasi dalam Program Peningkatan Kualitas Rehab Rumah Tidak Layak}

\section{Huni}

a. Partisipasi pasif dan manipulatif di sebagian besar kecamatan Payakumbuh Selatan. Di Kecamatan Payakumbuh Selatan untuk tahun 2017 pihak kelurahan, kelompok penerima bantuan dan masyarakat secara umum kurang tanggap. Karena pada tahun 2017 tersebut komunikasi berjalan kurang baik antara Dinas terkait dengan pihak kelurahan, sehingga pihak kelurahan kurang memberikan respon. Diantara permasalahannya adalah tidak adanya upah, proposal dan rencana anggaran biaya juga diserahkan ke pihak kelurahan sedangkan komunikasi kurang lancar. Bahkan ada penolakan yang terjadi dibeberapa kelurahan. Pihak fasilitator juga kurang berkoordinasi mengakibatkan kelurahan lepas tangan dan tidak ikut 
membantu mulai dari perencanaan dan pelaksanaan. Masyarakatpun (RT/RW, LPM, Niniak Mamak dan kerabat) kurang ikut serta dalam program sehingga nilai rata-rata swadaya Kecamatan Payakumbuh Selatan paling rendah.

b. Partisipasi Informatif, disini masyarakat hanya menjawab pertanyaan-pertanyaan untuk proyek, namun tidak berkesempatan untuk terlibat dan mempengaruhi proses keputusan, akurasi hasil tidak dibahas bersama masyarakat. Masyarakat disajikan informasi mengenai program PKRTLH oleh pihak fasilitator yang didampingi tim teknis dari dinas Perumahan Rakyat dan Kawasan Permukiman dan masyarakat tidak punya kesempatan untuk mempengaruhi keputusan mengenai prosedur dan tata laksana pekerjaan seperti termen waktu yangsudah ditentukan, anggaran yang sudah dipatok dan lain sebagainya.

c. Partisipasi konsultatif, masyarakat berpartisipasi dengan cara berkonsultasi, sedangkan orang luar mendengarkan serta menganalisis masalah dan cara pemecahannya. Dalam pola ini belum ada peluang untuk pembuatan keputusan bersama di mana para profesional tidak berkewajiban untuk mengajukan pandangan masyarakat (sebagai masukan) untuk ditindak lanjuti. Dalam program PK-RTLH ini pada dasarnya masyarakat hanya diminta melaksanakan program tersebut dengan berbagai aturan yang mengikat diantaranya:

1. Program diberikan hanya untuk yang mempunyai bukti kepemilikan tanah baik berupa sertifikat atau surat keterangan tanah sedangkan rata-rata masyarakat miskin tidak memiliki tanah padahal yang ada adalah tanah warisan pusako tinggi atau menumpang ditanah orang lain.

2. Penerima bantuan harus mengembalikan sejumlah uang yang disepakati dari awal jika pengerjaan rumah tidak selesai diakhir tahun. Padahal rata-rata keterlambatan karena ketidakberdayaan orang miskin dalam menyelesaikan pengerjaan rumah disebabkan tidak adanya upah dan rendahnya swadaya masyarakat sekitar. Walaupun hal tersebut belum terjadi karena anggota kelompok bertanggung jawab terhadap kelompoknya.

d. Partisipasi inisiatif, masyarakat memberikan pengorbanan dan jasa untuk memperoleh imbalan intensif berupa upah, walau tidak dilibatkan dalam proses pembelajaran atau eksperimeneksperimen yang dilakukan. Masyarakat tidak memiliki inisiatif dalam melanjutkan kegiatankegitan setelah intensif dihentikan. Seperti yang terjadi pada beberapa penerima bantuan mereka harus mengeluarkan upah untuk masyarakat yang berswadaya walaupun nilai uangnya tidak sebesar pada orang umumnya. Masyarakat berinisiatif ikut berpartisipasi padahal mengharapkan insentif berupa upah dan makanan. 
e. Partisipasi fungsional masyarakat membentuk kelompok sebagai bagian proyek, setelah ada keputusan utama yang disepakati. Pada tahap awal, masyarakat tergantung kepada pihak luar, tetapi secara bertahap kemudian menunjukan kemandiriannya. masyarakat membentuk kelompok-kelompok sebagai bagian dalam proyek rehab rumah yang walaupun pada tahap awal masyarakat bergantung pada Pemerintah dan Fasilitator namun pada akhirnya mereka mulai mandiri walaupun masih dipantau oleh pemerintah. Dimana untuk kota Payakumbuh sebagian besar di Kecamatan Payakumbuh Utara, Kecamatan Lampasi tigo nagari dan Kecamatan Payakumbuh Timur dapat dilihat karakteristik partisipasi fungsionalnya sebagai berikut:

1. Masyarakat membentuk kelompok-kelompok penerima bantuan guna mengelola sendiri bantuan. Terdapat banyak kelompok penerima bantuan biasanya dalam tiap kelurahan terdiri dari satu atau lebih kelompok, ketua kelompok bertanggung jawab terhadap anggotanya. Setiap anggota harus menyelesaikan pembangunan rumahnya karena jika pembangunan tidak selesai atau gagal maka penerima bantuan harus mengembalikan sejumlah uang sesuai nilai yang diberikan oleh Pemerintah.

2. Kelompok berusaha untuk mandiri walaupun masih bergantung pada pihak luar tetapi perlahan berusaha lepas dari pengaruh luar. Yang dimaksud pihak luar adalah Pemerintah.

f. Partisipasi interaktif, masyarakat berperan dalam proses analisis untuk perencanaan kegiatan dan pembentukan atau penguatan kelembagaan, pola ini cenderung melibatkan metode interdisipliner yang mencari keragaman perspektif dalam proses belajar yang terstruktur dan sistimatis. Pada saat ini program PK-RTLH masih belum sampai pada tingkatan partisipasi interaktif karena dalam program hanya melibatkan masyarakat secara umum seperti RT/RW, tokoh masyarakat, LPM dan Niniak Mamak dan disetiap kelurahan berbeda tingkatan partisipasinya. Belum mampu melibatkan pihak lain yang lebih profesional karena keterbatasan anggaran dan swadaya. Walaupun terdapat tim teknis (Camat dan Lurah terkecuali Dinas Perumahan Rakyat dan Kawasan Permukiman) tapi mereka hanya berperan pada tahap sosialisasi tidak sampai pada pelaksanaan, monitoring dan evaluasi.

g. Partisipasi mandiri adalah masyarakat mengambil inisiatif sendiri secara bebas (tidak dipengaruhi oleh pihak luar). Partisipasi mandiri adalah tingkatan partisipasi yang paling ideal dan untuk program PK-RTLH belum sampai pada tahap ini karena masyarakat walaupun bebas berswadaya tapi masih belum mampu membangun kontak dengan lembaga lain. Masyarakat masih bergantung pada fasilitator. Untuk mencapai tingkatan tertinggi dari partisipasi cukup 
sulit karena keterbatasan sumber daya masyarakat miskin, mereka terbelenggu oleh kemiskinan dan kebodohan karena tingkat pendidikan yang rendah tidak mampu untuk mengembangkan diri jika tidak ada yang mendorong diluar dirinya.

\section{Faktor Pemungkin dan Penghambat Partisipasi Masyarakat Dalam Program PK-RTLH}

1. Faktor Pemungkin Instrinsik

Menurut Bima (2018), faktor pemungkin (enabling factor) adalah faktor-faktor yang memungkinkan atau yang memfasilitasi perilaku seseorang. Adapaun yang menjadi faktor pemungkin intrinsik adalah:

a. Ikatan Kekerabatan

Partisipasi masyarakat muncul dari adanya rasa senasib sepenanggungan karena satu suku dan saparuik satu garis keturunan yang matrilineal sehingga masyarakat tergerak untuk turut serta melibatkan diri membantu masyarakat miskin yang membutuhkan. Faktor kebudayaan dalam arti adanya satu rasa dalam masyarakat berdasarkan rasa saling percaya, sama tujuan dan cita-cita serta adanya konsistensi dalam tindakan. Di kelurahan Tigo Koto Diatas ini masyarakat menyediakan satu hari dalam seminggu untuk bergotong royong membangun rumah si penerima bantuan, baik itu saudara maupun tetangga. Adanya peran RT dan Fasilitator dalam menggerakkan masyarakat untuk ikut turut serta disamping masyarakat yang peka dan tanggap terhadap masyarakat miskin atau rentan ekonomi disekitarnya.

a. Keinginan Untuk Hidup Layak

Keinginan untuk dapat meningkatkan kualitas penghidupan menjadi salah satu faktor yang menyebabkan timbulnya partisipasi masyarakat dalam program PK-RTLH. Motivasi tersebut disatu sisi, dari sudut si penerima bantuan yang sangat ingin rumahnya menjadi tempat tinggal yang nyaman untuk didiami. Dari sisi masyarakat sekitar yang ikut bergotong-royong, motivasi timbul dari rasa simpati dan solidaritas sosial agar salah satu warga mereka yang berekonomi lemah, dapat hidup lebih layak dengan adanya bantuan perbaikan rumah.kedua motivasi ini lah yang kemudian bertemu dan menjadi salah satu faktor yang menyebabkan tingginya partisipasi masyarakat pada implementasi progam.

\section{Faktor Pemungkin Ekstrinsik}

Menurut Holil dalam (Akhmadian dan Anton, 2015) ada beberapa hal yang dapat mempengaruhi partisipasi masyarakat yang berasal dari luar/lingkungan (ekstrinsik). Dalam 
penelitian ini memakai konsep operasional berdasar temuan di lapangan bahwa hal yang mendorong orang berpartisipasi dari luar dirinya (ekstrinsik) adalah sebagai berikut :

a. Kekompakan Kelompok

Dalam program PK-RTLH terdapat kelompok penerima bantuan (KPB) minimal dalam satu kelurahan terdapat satu kelompok yang terdiri dari 10 orang lebih. Kelompok terdiri dari ketua, sekretaris dan bendahara serta anggota. Setiap kelompok bertanggung jawab akan semua anggota kelompoknya, dimana jika ada satu rumah yang tidak selesai atau gagal maka penerima bantuan tersebut harus mengembalikan bantuan tersebut utuh. Untuk menghindari sanksi tersebut maka ketua punya tanggung jawab mengkoordinir anggotanya.

b. Waktu luang

Masyarakat yang punya waktu luang tentunya dapat ikut serta berpartisipasi. Walaupun terlihat sebagai variabel yang sederhana, namun ternyata adanya waktu luang, memiliki pengaruh yang cukup signifikan dalam menimbulkan partisipasi masyarakat. Terutama pada masyarakat perkotaan yang heterogen seperti di Kota Payakumbuh.

\section{Faktor Penghambat Partisipasi Masyarakat}

Ada beberapa hal yang membuat orang enggan berpartisipasi, padahal partisipasi itu penting untuk mendukung program pembangunan diantaranya adalah sebagai berikut:

a. Faktor ekonomi penghambat partisipasi masyarakat dalam PK-RTLH

Dorongan ekonomi tetap mendominasi sikap dan perilaku masyarakat dalam ikut berpartisipasi membantu rehab rumah. Masyarakat kurang berminat atau enggan untuk berpartisipasi karena keterbatasan ekonomi sebab masyarakat yang berada disekitar mereka adalah masyarakat yang rata-rata menengah kebawah. Sebagian besar berprofesi sebagai petani, buruh, dan pedagang yang tiap hari bekerja sehingga tidak punya waktu luang untuk membantu.

b. Pengaruh modernisasi sehingga muncul sifat individualis

Rendahnya partisipasi sangat terlihat di daerah yang padat penduduk dan didominasi oleh pendatang. Sehari-hari mencari uang, dan bersifat individualis dan kurang peka dengan lingkungan. Untuk mengikuti rapat di kantor lurah saja mereka tidak punya waktu karena kesibukan diluar. Berbeda halnya dengan daerah pinggiran Kota Payakumbuh seperti Kelurahan Koto Panjang Dalam dan Kelurahan Tigo Koto Diateh masyarakatnya sangat peka karena informasi mengenai program sampai pada mereka.

c. Informasi program tidak sampai ke semua unsur masyarakat 
Salah satu faktor penghambat orang untuk berpartisipasi adalah kurangnya informasi yang disampaikan karena sosialisasi hanya di Kantor Lurah saja, RT/RW tidak menyampaikan informasi ke warganya. Pada tahun 2017 sosialisasi dilaksanakan untuk Camat dan Lurah, informasi yang didapat tidak sampai ke RT/RW dan LPM oleh Lurah. Padahal diharapkan Lurah memfasilitasi dan memberikan informasi tidak hanya kepada calon penerima tetapi juga pada semua masyarakat.

\section{KESIMPULAN DAN SARAN}

Berdasarkan pembahasan dari hasil peneilitian maka dapat ditarik kesimpulan sebagai berikut:

Tingkatan partisipasi dalam program Peningkatan Kualitas Rehab Rumah Tidak Layak Huni di Kota Payakumbuh berbeda di tiap kecamatan dan kelurahan. Penerimaan masyarakat bergantung kepada kemampuan Dinas Perumahan Rakyat dan Kawasan Pemukiman, fasilitator, lurah, RT/RW dan tokoh masyarakat dalam menggala partisipasi. Kelurahan yang berada di pinggir kota Payakumbuh seperti kelurahan Koto Panjang Dalam dan kelurahan Tigo Koto Diateh rata-rata tingkatan partisipasinya tinggi. Hal ini dapat dilihat dari tingkat kehadiran saat rapat atau rembuk warga kemudian partisipasi saat pembangunan berlangsung. Bentuk partisipasi mereka berupa tenaga, materi dan keahlian. Namun ada juga yang ditengah kota dengan hasil pembangunan terbaik di kelurahan Padangtangah Balai Nanduo Kecamatan Payakumbuh Barat, hal tersebut disebabkan oleh kesadaran pihak keluarga besar, sanak saudara dan tetangga. Hal ini tidak berlaku umum, karena di tengah kota dengan penduduk yang padat tingkat kesadaran sosialnya rendah.

Ada berbagai faktor pemungkin dan penghambat masyarakat berpartisipasi dalam program PK-RTLH di kota Payakumbuh. Faktor pemungkin ada yang bersifat intrinsik dan ada yang bersifat ekstrinsik. Untuk yang bersifat intrinsik adalah: a) ikatan kekerabatan bahwa orang mau berpartisipasi karena samande, saparuik, sajurai dan sasuku dan b) keinginan untuk hidup layak. Sedangkan faktor pemungkin yang bersifat ekstrinsik adalah sebagai berikut: a) Kerjasama kelompok, dan b) waktu luang. Faktor penghambat partisipasi masyarakat di Kota Payakumbuh salahsatunya adalah motivasi ekonomi. Masyarakat yang hidup dibawah garis kemiskinan berjuang untuk bertahan hidup mereka tidak punya kemampuan finansial untuk membantu secara materi sedangkan untuk memberikan bantuan tenaga pun mereka tidak sanggup karena tidak punya waktu luang yang disebabkan harus mencari nafkah setiap hari.

Kemampuan pemerintah untuk memberikan stimulan juga terbatas. Belum semua masyarakat yang mendapat bantuan. Banyak kendala dilapangan seperti masyarakat yang menerima bantuan 
diharuskan memiliki setifikat atau bukti kepemilikan sendiri dan juga komitmen untuk mencari tukang dan menyelesaikan sampai akhir. Persyaratan yang berat membuat sebagian orang yang layak menerima bantuan menjadi menolak bantuan.

\section{SARAN}

Berdasarkan hasil penelitian dari peneliti maka saran yang dapat diberikan adalah sebagai berikut:

1. Pemerintah ditingkat bawah (kelurahan) dan didukung oleh Camat agar dapat memfasilitasi program PK-RTLH di kelurahan agar dapat menggerakkan partisipasi masyarakat bersama dengan RT/RW, LPM, Niniak Mamak agar swadaya yang diberikan oleh masyarakat meningkat dari sebelumnya.

2. Perlunya sosialiasi yang dimulai dari tingkat bawah (jemput bola) ke RT/RW, Niniak Mamak, LPM agar mereka memahami pentingnya partisipasi masyarakat dalam program PK-RTLH karena bantuan yang diberikan oleh Pemerintah hanya berupa stimulan.

3. Perlu dilakukan uji materi Peraturan Menteri PUPR terkait persyaratan legalisasi tanah calon penerima bantuan. Perlu dipertimbangkan kearifan lokal masyarakat minang kabau yang memiliki harta pusaka tinggi yang tidak dapat dibagi-bagi, untuk itu perlu dikaji jika masyarakat miskin calon penerima bantuan dapat mengajukan bukti kepemilikan berupa hak guna yang disepakati oleh niniak mamak kaum.

\section{DAFTAR PUSTAKA}

Afrizal, (2016). Metode Penelitian Kualitatif, Sebuah Upaya Mendukung Penggunaan Penelitian Kualitatif Dalam Berbagai Disiplin Ilmu. Jakarta: PT Raja Gravindo Persada.

Akhmadian dan Anton. (2015). Partisipasi Masyarakat Dalam Mewujudkan Kuningan Sebagai Kabupaten Konservasi. Jurnal Unifikasi. Vol 2 No 1

Arikunto, Suharsimi. (2002). Manajemen Penelitian, Jakarta: Rineka Cipta.

Bappenas. (2004). Strategi Nasional Penanggulangan Kemiskinan Bab II diakses melalui http://www.bappenas.go.id/index.php pada tanggal 9 April 2007.

Bima, I. P., Roesdiyanto., R. W. Gayatri. (2018). Hubungan Faktor Predisposisi, Faktor Pemungkin, dan Faktor Penguat dengan Perilau Merokok Pelajar SMKN 2 Kota Probolinggon Tahun $2017: 2$

Bintarto, R. (1984). Urbanisasi dan Permasalahannya. Jakarta : Ghalia Indonesia Badan Pusat Statistik, berbagai edisi Brockerhorff, M dan Brennan. 1998. "The Poverty of Cities in Developing Regions". Population and Development Review 24, no. 1. 
Budiman, Arief. (1995). Teori Pembangunan Dunia Ketiga. Jakarta: PT Gramedia Pustaka Utama.

Carnea, M. (1988). Putting people First in Development. Washinton DC: World Bank.

Didik Suharjito. (2006). Berbagi Pengalaman Pendampingan Masyarakat Desa dalam Pengelolaan Sumber Daya Hutan. Yogyakarta: Debut Pers.

Dewinta, Nadia. (2011). Pelaksanaan Program Rehabilitasi Sosial Rumah Tidak Layak Huni (RSRTLH) Bagi Keluarga Miskin di Kecamatan Bintan Timur Kabupaten Bintan Tahun 2011. Pekanbaru. Fakultas Ilmu Sosial dan Ilmu Politik. Universitas Riau.

Effendi, Tajudin Noor. (1993). Sumber Daya Manusia, Peluang Kerja dan Kemiskinan. Yogyakarta: Tiara Wacana Yogya.

Erwin. (2015). Model Pemberdayaan Masyarakat Mentawai melalui Penguatan Kelembagaan Lokal di Pulau Siberut. Sosio Konsepsia, 4(2), 1-14.

Erwin. (2006). Tanah komunal: memudarnya solidaritas sosial pada masyarakat matrilineal Minangkabau. Fakultas Ilmu Sosial dan Ilmu Politik, Universitas Andalas.

Hermawan, Y, YoyonSuryono. (2016). Partisipasi Masyarakat Dalam Penyelenggaraan Program-Program Pusat Kegiatan Belajar Masyarkat Ngudi Kapinteran.Jurnal Pendidikan dan Pemberdayaan Masyarakat. Volume 3.

Heryana, Ade. (2018). Informan dan Pemilihan Informan Dalam Penelitian Kualitatif. Universitas Esa Unggul.

James, Midgley. (1995). Social Development : The Development Perpektif in social Welfare. London: Sage Publication Inc.

Kamaluddin, Rustian. (2003). Kemiskinan Perkotaan di Indonesia : Perkembangan, Karakteristik dan Upaya Penanggulangan diakses melalui http://www.bapedajabar.go.id/bapeda_design/docs/perenca naan/20070530_105946.pdf.

Khori. (2013). Analisis Pelaksanaan Bantuan Rehabilitasi Rumah Tidak Layak Huni di Desa Teluk Siantan Kecamatan Siantan Tengah Kabupaten Kepulauan Anambas. Fakultas Ilmu Ekonomi dan Ilmu Sosial. UIN Suska Riau.

Korten, D.C dan Syahrir. (1988). Pembangunan Berdimensi Kerakyatan. Jakarta: Yayasan Obor Indonesia.

Kuncoro, Mudrajad (2010) Masalah, Kebijakan, Dan Politik Ekonomika Pembangunan. Jakarta: Penerbit Erlangga.

Mahyuddin, Thursina. (2013). Analisis Partisipasi Masyarakat Dalam Pelaksanaan Program Pembangunan Pengaman Pantai di desa Teulaga Tujuh (Pusong) Kecamatan Langsa BaratKota Langsa. Jurnal Perspektif. Volume 6 No: 2 
Matdoan, Usman. (2015). Peranan Program PNPM-Mandiri Pedesaan Dalam Mendorong Partisipasi dan Pemberdayaan Masyarakat Lokal. Jurnal Biology Science \& Education. Vol 4 No 1

Mulyanto, S dan H.D. Evers. (1982). Kemiskinan dan Kebutuhan Pokok. Jakarta: CV Rajawali.

Nat J.C dan U. Kayam. (1987). Kebudayaan dan Pembangunan: Sebuah pendekatan terhadap Antropologi Terapan di Indonesia. Jakarta: Yayasan obor Indonesia.

Nugroho dan Dahuri. (2002). Pembangunan Wilayah-Perspektif Ekonomi, Sosial dan Lingkungan. Jakarta : LP3ES.

Pronk, JP. (1993). Sedunia Perbedaan, Sebuah Acuan Baru Dalam Kerja Sama Pembangunan Kerjasama Tahun 1990-an. Yayasan Obor. Jakarta. Indonesia: 421 hlm.

Sugiyono. (2009). Metode Penelitian Pendidikan Pendekatan Kuantitatif, Kualitatif dan R\&D. Bandung: Alfabeta. 